\title{
HIGH ALTITUDE CHIRONOMIDAE (DIPTERA) OF SERRA DA ESTRELA (PORTUGAL): ADDITIONS TO THE PORTUGUESE AND IBERIAN PENINSULA FAUNA
}

\author{
M. Rieradevall*, M. L. Chaves** \& N. Prat*
}

\begin{abstract}
A Chironomidae (Diptera) fauna list for headwater streams of high altitude areas in Serra da Estrela (Portugal) is presented, doubling the previously established species richness for the region. The findings include 17 new records for Portugal, which represent an increase to 219 species for the Continental Portugal Chironomidae fauna. Two new records were detected for the Iberian Peninsula: one species (Tvetenia duodenaria), and one subgenus -Psectrocladius (Mesopsectrocladius)-; and the presence of the genus Natarsia is confirmed. The last two occurrences correspond to monoespecific taxa of the Palearctic region. However, as taxonomic identification has been based on larval material, instead of pupae, pupal exuviae or imagoes, species level assignment is still uncertain.

Key words: Diptera, Chironomidae, high mountain streams, Serra da Estrela, Portugal, Iberian Peninsula.
\end{abstract}

\section{RESUMEN}

Quironómidos (Diptera, Chironomidae) de alta montaña de la Sierra de Estrela (Portugal) y adiciones a la fauna de Portugal y la Península Ibérica

Se presenta una lista de especies de Chironomidae (Diptera) recolectados en los ríos de cabecera de zonas de alta montaña en la Serra da Estrela (Portugal). Con esta aportación se duplica la riqueza de especies regional conocida hasta el momento y se eleva la fauna de quironómidos del Portugal continental a 219 especies. Se incluyen dos nuevas citas para la Península Ibérica, una especie (Tvetenia duodenaria) y un subgénero -Psectrocladius (Mesopsectrocladius)-, y se confirma la presencia del género Natarsia. En los dos últimos casos se trata de larvas de taxones hasta el momento monoespecíficos en la región paleárctica, pero al no haberse recolectado pupas o adultos no se puede asegurar la identificación específica.

Palabras clave: Diptera, Chironomidae, ríos de alta montaña, Serra da Estrela, Portugal, Península Ibérica.

* Departamento de Ecología, Facultad de Biología, Universitat de Barcelona. Diagonal 645. 08028- Barcelona (Spain).

** Universidade de Lisboa, Faculdade de Ciências, Instituto de Oceanografia, Campo Grande, 1749-016, Lisboa (Portugal). 


\section{Introduction}

Chironomids are one of the most abundant and diverse group of aquatic insects inhabiting freshwater systems, particularly in alpine headwater streams (Castella et al., 2001; Lods-Crozet et al., 2001a; 2001b; Maiolini \& Lencioni, 2001) and lakes (Rieradevall et al., 1998, Rieradevall \& Prat, 1999, 2000; Füreder et al., 2006). These areas have great biogeographical interest due to the presence of both euryoecious and cold-stenothermal species, which cannot cross geographical barriers formed by warmer lowland waters. The westernmost high-mountain system in continental Europe is Serra da Estrela in Portugal (1993 $\mathrm{m}$ a.s.1.), although it is not as high as other alpine ranges such as the Pyrenees or the Alps. Knowledge of macroinvertebrate fauna and especially of chironomids in Serra da Estrela is still limited to rivers and streams below $1400 \mathrm{~m}$ a.s.l. (Reiss, 1989; Cobo et al., 2001) and high mountain lakes above $1615 \mathrm{~m}$ a.s.1. (Rieradevall \& Prat, 1999). Five intermittent headwater streams located above $1400 \mathrm{~m}$ a.s.l. were studied in the present work, which is part of a larger study on the benthic macroinvertebrate community of these high altitude streams (see Chaves et al., in press). The main objective of the present paper is to improve the knowledge of Serra da Estrela freshwater biodiversity, namely with respect to the Chironomidae fauna.

\section{Material and methods}

Biological data was collected in five different intermittent headstreams located within the
Mondego River basin, in Serra da Estrela Natural Park (Table 1). Distance between sites ranged from $16 \mathrm{~km}$ to $0.5 \mathrm{~km}$. Therefore, all sites presented very similar climatic and geological conditions and fit within a single stream type $(>800 \mathrm{~m}$ a.s.1., siliceous geology, with less than $10 \mathrm{~km}^{2}$ of catchment area).

The five intermittent stream sites were sampled on six occasions, at approximately four to six-weekly intervals, from late April 2004 to early November 2004. All five streams dried up to form pools in summer. Streams 1 and 2 were totally dry during one sampling occasion (July) and streams 4 and 5 during three sampling occasions (from July to mid October). More information about ecological functioning and benthos structure at these localities can be found in Chaves et al. (in press).

Pupae and pupal exuviae of Chironomidae were collected by applying the methodology indicated by Langton \& Casas (1998), using a hand-net of $250 \mu \mathrm{m}$ mesh size. Care was taken to include all possible habitats over representative sections of the stream (10 m samples). Samples were preserved in situ in $96 \%$ ethanol, rinsed using a $250 \mu \mathrm{m}$ mesh sized sieve, sorted under magnification and preserved in $70 \%$ ethanol.

Pupal exuviae (Pe), pupae and pharate imagoes (Pm for male pupae, and Pf for female pupae), and larvae were prepared for taxonomical identification following current methods, which included, when necessary, bathing in a warm $10 \%$ potassium hydroxide solution for clearing the specimen, rinsing with distilled water, dehydrating in $70 \%$ and $90 \%$ ethanol and mounting in

Table 1.- Location and physiographic characteristics of each of the five stream sites studied. All sites are within the Mondego River basin in Serra da Estrela (Portugal).

Tabla 1.- Localización y características fisiográficas de los cinco ríos de cabecera estudiados en la cuenca del río Mondego en Serra da Estrela (Portugal).

\begin{tabular}{|c|c|c|c|c|c|}
\hline \multirow[b]{2}{*}{ Variables } & \multicolumn{5}{|c|}{ Streams } \\
\hline & 1 & 2 & 3 & 4 & 5 \\
\hline Latitude (North) & $40^{\circ} 21.840$ & $40^{\circ} 21.775$ & $40^{\circ} 21.445$ & $40^{\circ} 25.700$ & $40^{\circ} 24.244$ \\
\hline Longitude (West) & $7^{\circ} 37.847$ & $7^{\circ} 37.713$ & $7^{\circ} 37.630$ & $7^{\circ} 35.653$ & $7^{\circ} 35.172$ \\
\hline Distance from source $(\mathrm{km})$ & 0.38 & 0.40 & 2.00 & 0.73 & 0.50 \\
\hline Altitude (m a.s.1.) & 1673 & 1664 & 1629 & 1400 & 1470 \\
\hline Drainage basin $\left(\mathrm{km}^{2}\right)$ & 0.08 & 0.15 & 2.16 & 0.20 & 0.13 \\
\hline Tributary of & $\begin{array}{c}\text { Ribeira da } \\
\text { Lagoa (Alva) }\end{array}$ & $\begin{array}{c}\text { Ribeira da } \\
\text { Lagoa (Alva) }\end{array}$ & $\begin{array}{c}\text { Ribeira da } \\
\text { Lagoa (Alva) }\end{array}$ & $\begin{array}{c}\text { Ribeira do } \\
\text { Cabaço (Alva) }\end{array}$ & $\begin{array}{c}\text { Ribeira da } \\
\text { Fervença (Alva) }\end{array}$ \\
\hline
\end{tabular}




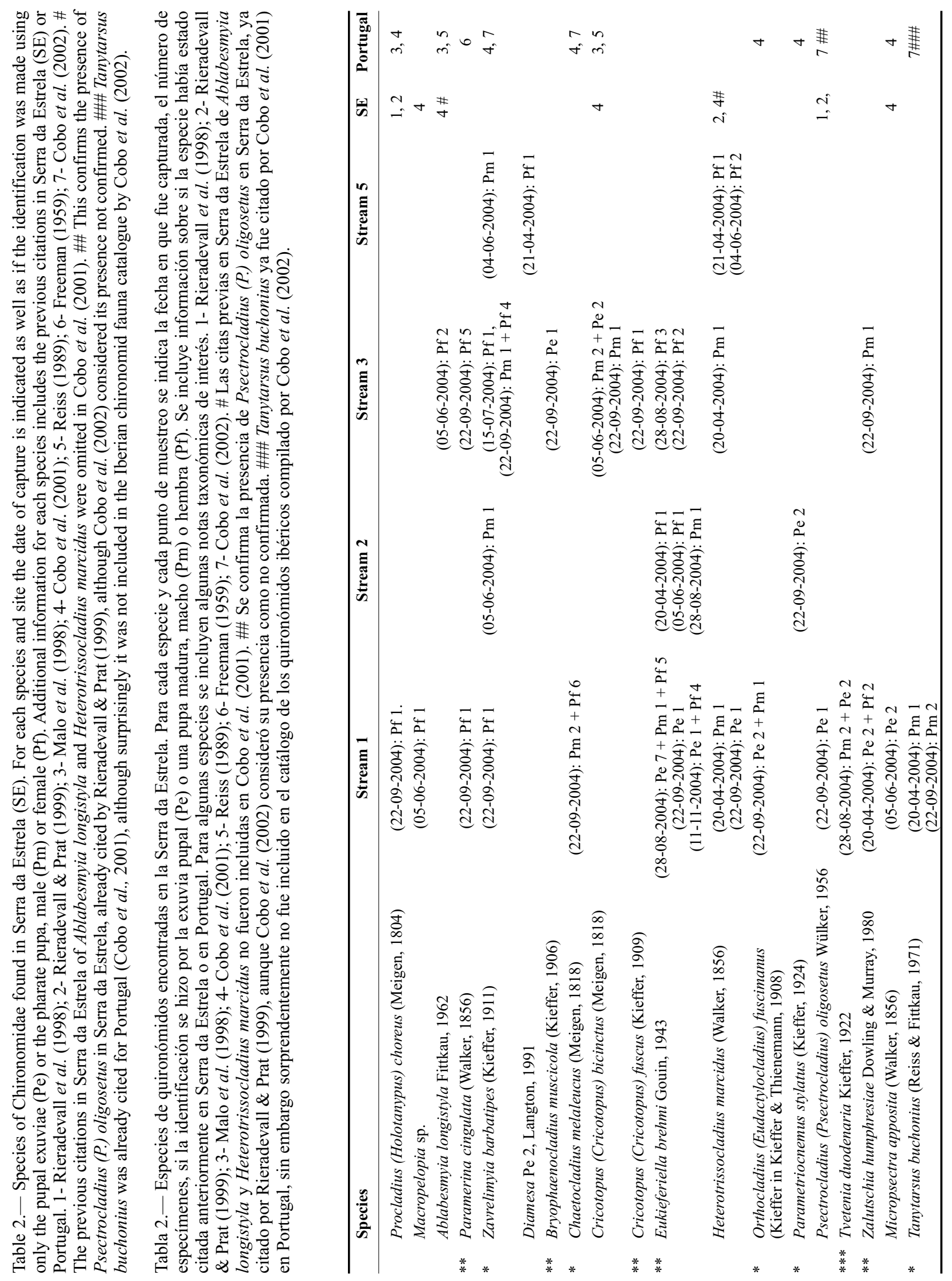


Table 3.- Chironomidae taxa found in the 5 headwater streams sampled in Serra da Estrela (Portugal) identified using larvae. When the genus is monotypic in the Western Palearctic region, as for Natarsia, Pseudokiefferiella or Stilocladius, we have assigned the corresponding species name in brackets.

Tabla 3.- Taxones de quironómidos identificados en los 5 ríos de cabecera muestreados en la Serra da Estrela (Portugal) de acuerdo a las larvas encontradas. Cuando el género es monotípico en la región Paleárctica Occidental, como es el caso de Natarsia, Pseudokiefferiella o Stilocladius, se ha asignado el nombre específico correspondiente entre corchetes.

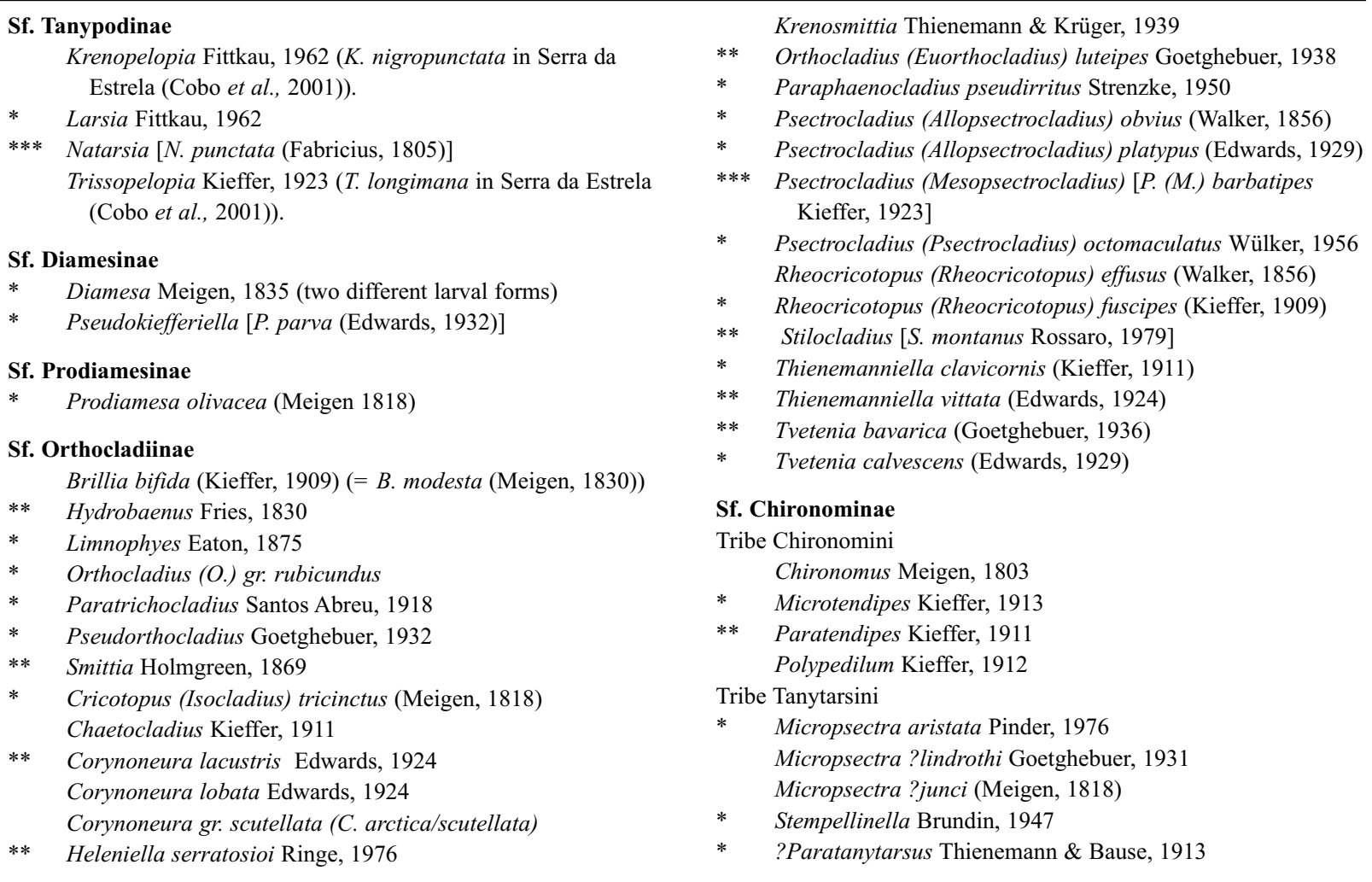

Euparal media. Pupal skins were identified following Langton's (1991) key. These microscope slides are deposited in Dr. Rieradevall's collection at the University of Barcelona. For larvae identification we used mainly Wiederholm (1983) and Schmid (1993) together with miscellaneous bibliography, and Dr. Rieradevall's reference collection from Iberian mountain lakes and streams. This collection material allowed the correlation between several larvae specimens and their pharate adults and consequently the development of Corynoneura and Micropsectra unpublished identification keys that helped in the present identifications.

\section{Results and Discussion}

Species identified using pupaes and pupal exuviae during the present study are presented in Table 2 , with indication of stream and collection date and type and quantity of examined material. For completeness and due to the relevance of some findings, we also present a check list of chironomid taxa (genus and/or species) that were identified using larval material exclusively (Table 3 ). In this table, when the genus is monotypic in the Western Palearctic region, as for Natarsia, Pseudokiefferiella or Stilocladius, we have assigned the corresponding species name in brackets.

New records for the Iberian Peninsula, Portugal and Serra da Estrela are indicated by ***,** and *, 
respectively in both tables. Chironomid species assemblages in the five headwater streams studied accounted for 62 taxa, including representatives of subfamily Tanypodinae (9 taxa), Diamesinae (3), Prodiamesinae (1), Orthocladiinae (38), and Tribes Chironominii (4) and Tanytarsinii (7).

Forty-two taxa are new for Serra da Estrela, updating the Chironomidae fauna richness of this area to a total of 85 taxa, from the 43 reported up to now (Cobo et al., 2001). These findings include 17 new records for Portugal, which represent an upgrade from the 202 previously detected taxa (Cobo et al., 2002) to 219 species for the Continental Portugal Chironomidae fauna. One of these taxa is a new species record for the Iberian Peninsula (Tvetenia duodenaria Kieffer, 1922) and two are new monotypic genus and subgenus records for the same region (Natarsia (presumably N. punctata (Fabricius, 1805)), and Psectrocladius (Mesopsectrocladius) presumably (P. (M.) barbatipes Kieffer, 1923) respectively). In the case of Natarsia this is the confirmation of its presence in the Iberian Peninsula, as although already cited by Czerny \& Strobl (1909), the posterior references (Arias, 1912; Cobo et al., 1987 and Soriano et al., 1997) are just citations of the same old and only source of information. Maybe because of that Cobo et al. (2002) omitted the inclusion of Natarsia in their Iberian Chironomidae catalogue. Three new genera records for continental Portugal are included: Hydrobaenus, Smittia, and Paratendipes. The remaining identifications represent an expansion of their known altitudinal range in Portugal. Since different material types (pupal exuviae, pupae, pharate imagoes and larvae) were used for taxonomic identification, only six taxa (those identified with pupal exuviae) can be considered as consistent new species cites, while the remaining taxa (11) need further confirmation with supplementary pupal or imagoes specimens.

As Tvetenia duodenaria is recorded for the first time in the Iberian Peninsula, and because we found some morphological differences with the data provided from other regions, we include some taxonomic remarks about this species from the material examined in Serra da Estrela. Thus, the observed male genitalia and pupal skins agreed with Lehman's (1972) descriptions, although the relative length of the thoracic horn filament with respect to the base was not as long in the Portuguese material as in the previously described material: 2.54 times vs. 6, respectively. Langton (com. pers., 2006) found great variability in this species character, similarly to other Orthocladiinae species. Thoracic horn base length is 0.34 of the thoracic horn total length instead of the expected 0.16-0.19 ratio originally indicated by Langton (1991). This ratio fitted better the description of Dratnalia potamophylaxi (Fittkau \& Lellak, 1971) in Langton's key (op. cit.), although the tergite I morphology did not agree.

\section{ACKNOWLEDGMENTS}

We thank Ana Rego, Joana Marques, Luzia Borges, Paula Chainho and Tiago Marques for technical assistance in the collection of field data. The help of colleagues from the Oceanographic Institute of the University of Lisbon, specially M.J. Costa and J.L. Costa, is deeply acknowledged. This work was financially supported by a grant to M.L.C. (SFRH/BD/6365/2001).

\section{References}

ARIAS, J., 1912. Adiciones a la fauna dipterológica de España. Boletín de la Real Sociedad Española de Historia Natural, XII: 385-427.

Castella, E., Adalsteisson, H., Brittain, J. E., Gislason, G. M., Lehmann, A., Lencioni, V., LodsCrozet, B., Maiolini, B., Milner, A. M., Olafsson, J. S., Saltveit, S. \& SNOOK, D. L., 2001. Macrobenthic invertebrate richness and composition along a latitudinal gradient of European glacier-fed streams. Freshwater Biology, 46: 1811-1831.

Chaves, M. L., Rieradevall, M., Chainho, P., Costa, J. L., Costa, M. J. \& Prat. N. in press. Macroinvertebrate communities of non-glacial high altitude intermittent streams. Freshwater Biology.

Cobo, F., Jiménez, M. T., Casas, J. J., Vílchez, A., Soriano, O., Sevillano, M., Rieradevall, M., MuÑoz, I. \& PRAT, N., 1987. Inventario faunístico de los quironómidos conocidos de la Península Ibérica. Alquibla, 12: 56-65.

Cobo, F., Soriano, O. \& BÁEz, M., 2002. Chironomidae. In: Carles-Tolrà, M. (coord.). Catálogo de los Diptera de España, Portugal y Andorra. Monografias S.E.A. 8: 35-44.

Cobo, F., Soriano, O. \& GonzÁlez, M. A., 2001. Inventario de los quironómidos (Diptera: Chironomidae) de Portugal. Nova Acta Cientifica Compostelana (Biología), 11: 225-248.

Czerny, L. \& Strobl, G., 1909. Spanische Diptera III, Beitrag. Verhandlungen der kaiserlich-königlichen zoologisch-botanischen Gesellschaft in Wien, 59: 121-301.

Füreder, L., Ettinger, R., Boggero, A., Thaler, B. \& THIES, H., 2006. Macroinvertebrate diversity in alpine lakes: effects of altitude and catchment properties. Hydrobiologia, 562: 123-144. 
Langton, P. H., 1991. A key to pupal exuviae of West Paleartic Chironomidae. Privately published. Huntington. 386 pp.

LAngton, P. H. \& CASAs, J., 1998. Changes in chironomid assemblage composition in two Mediterranean mountain streams over a period of extreme hydrological conditions. Hydrobiologia, 390: 37-49.

LEHMANN, J., 1972. Revision europäischerarten (puppen males and imagines males) der gattung Eukiefferiella Thienemann. Beitrage zur Entomologie, 22(7/8): 347-405.

lods-Crozet, B., Castella, E., Cambin, D., Ilg, C., Knispel, S., \& Mayor-Simeant H., 2001a. Macroinvertebrate community structure in relation to environmental variables in a Swiss glacial stream. Freshwater Biology, 46: 1641-1661.

Lods-Crozet, B., Lencioni, V., Ólafsson, J. S., Snook, D. L., Velle, G., Brittain, J. E., Castella, E., \& Rossaro, B., 2001b. Chironomid (Diptera: Chironomidae) communities in six European glacier-fed streams. Freshwater Biology, 46: 1791-1809.

Maiolini, B. \& LenCiOnI, V., 2001. Longitudinal distribution of macroinvertebrate assemblages in a glacially influenced stream system in the Italian Alps. Freshwater Biology, 46: 1625-1639.

Malo, J., Morais, M. \& Pinto, P., 1998. A contribution to the knowledge of the chironomid fauna (Diptera) in southern Portugal. Annales de Limnologie, 34(2): 165-170.

REISS, F., 1989. Erster Beitrag zur Chironomidenfauna Portugals (Diptera: Chironomidae). Nachrichtenblatt der Bayerischen Entomologen, 38(2): 46-50.

Rieradevall, M., JimÉnez, M. \& Prat, N., 1998. The zoobenthos of six remote mountain lakes in Spain and Portugal. Verhandlungen - Internationale Vereinigung für Theoretische und Angewandte Limnologie, 26: 2132-2136.

Rieradevall, M. \& Prat, N., 1999. Chironomidae from high mountain lakes in Spain and Portugal- In: Hoffrichter, O. (ed.). Late $20^{\text {th }}$ century Research on Chironomidae: An Anthology from the $13^{\text {th }}$ International Symposium on Chironomidae. Shaker Verlag. Aachen: 605-613.
RieradeVall, M. \& Prat, N., 2000. El zoobentos en los lagos y lagunas de alta montaña de la Península Ibérica y su interés como indicadores de cambios ambientales. In: Granados, I. \& Toro, M. (eds.) Conservación de los lagos y humedales de alta montaña de la península Ibérica. Colección de Estudios, Universidad Autónoma de Madrid. Madrid: 187-200.

SCHMid, P. E., 1993. A key to the larval Chironomidae and their instars from Austrian Danube region streams and rivers with particular reference to a numerical taxonomic approach. Part I. Diamesinae, Prodiamesinae and Orthocladiinae. Wasser und Abwasser Supplementband, 3/93: 1-514.

Soriano, O., Cobo, F., Rieradevall, M. \& Prat, N., 1997. Lista faunística y bibliográfica de los quironómidos (Diptera, Chironomidae) de la Península Ibérica e Islas Baleares. Colección Listas de la flora y fauna de las aguas continentales de la península ibérica, $n^{\circ}$ 13. Asociación Española de Limnología. Madrid. 210 pp.

Wiederholm, T., (ed.). 1983. Chironomidae of the Holarctic region. Keys and diagnoses. Part I. Larvae. Entomologica Scandinavica. Supplement, 19: 1-457.
Recibido, 20-IV-2007

Aceptado, 25-X-2007 Publicado, 27-XII-2007 